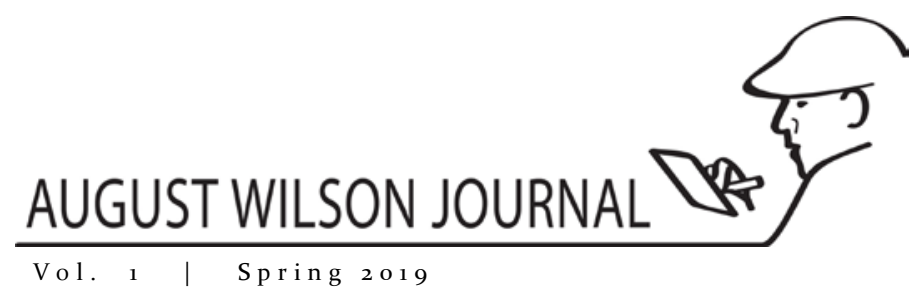

\title{
August Wilson Estate, Pittsburgh Post-Gazette, and August Wilson House Establish August Wilson Century Cycle Awards
}

\author{
By Christopher Rawson \\ Professor Emeritus, University of Pittsburgh \\ Theater Critic, Pittsburgh Post-Gazette \\ Office, August Wilson House
}

[August] remains most at home in the people, places and stories from what we call August Wilson's Hill, and in the theaters that bring them to life. The August Wilson American Century Cycle Award celebrates the conjunction of the two.

- Christopher Rawson

\begin{abstract}
August Wilson House, the August Wilson Estate, and the Pittsburgh Post-Gazette have teamed-up to celebrate the work of August Wilson by co-sponsoring the August Wilson Century Cycle Awards for those theaters that have successfully staged all ten plays of the Cycle.
\end{abstract}

Keywords

August Wilson, American Century Cycle Awards, August Wilson Estate, Pittsburgh Post-Gazette, American Stage, Hattiloo Theatre, Pittsburgh Playwrights Theatre, Goodman Theatre, Yale Rep, Huntingdon Theatre Company, O'Neill Theater Center, Pittsburgh Public Theatre, Penumbra, Christopher Rawson

August Wilson's creative imagination and the rich life of his native Hill District can take his 10-play American Century Cycle only so far. The Cycle can complete its full journey only in what has proved to be its ultimate home, the mainly not-for-profit theaters countrywide. So while interviewing and reviewing Wilson since 1983 for the Pittsburgh Post-Gazette and teaching an August Wilson course at the University of Pittsburgh (which he urged me to do), I began tracking which theaters had completed their own Cycle.

Flash forward, and to celebrate those theaters, the PostGazette, supported by August Wilson House and with the collaboration of Constanza Romero Wilson and the August Wilson Estate, established the August Wilson American Century

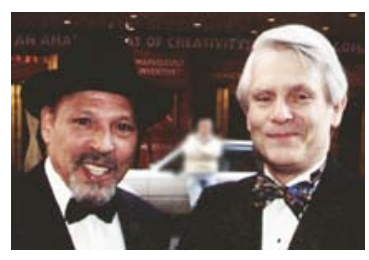

August and Chris Rawson Cycle Award. It's just a plaque, but there's nothing "just" about a theater's commitment that it measures. At present, some 17 theaters have qualified (see the adjacent list). If we'd started when the first theater completed its Cycle, we could have honored each theater in its turn, but now we're playing catch up, presenting each award as travel and schedules allow, at a ceremony arranged at each theater's convenience. Soon, a 
larger plaque listing all the qualifying theaters will hang in August Wilson House at 1727 Bedford Avenue, when the current restoration is completed.

So far we have presented seven awards. The first was to American Stage in St. Petersburg in 2017, just as they completed their Cycle with Joe Turner's Come and Gone. I went to Seattle Rep in early 2018, when they were doing their second Two Trains Running. Ms. Romero joined in that presentation, as she did for Mark Clayton Southers' Pittsburgh Playwrights Theatre on April 27, 2018, Wilson's $73^{\text {rd }}$ birthday. The next month I was in Houston to present the award to Eileen Morris' Ensemble Theatre, which threw a great reunion and party, and then Memphis when Ekundayo Bandele's Hattiloo Theatre was doing completing its Cycle with Ma Rainey's Black Bottom.

Pittsburgh Public Theater received its plaque last summer on the night it welcomed its new artistic director, Marya Sea Kaminski. In November, the Anthony Bean Community Theatre in New Orleans threw itself a fund-raiser and received its plaque from Pittsburgh's Wali Jamal, the only actor to have completed a Super Cycle - the 1o plays plus Wilson's autobiographical How I Learned What I Learned. (In time, we hope to honor actors' and directors' Cycles, but theaters first.)

Going back, the first to complete the Cycle was Chicago's Goodman Theatre, beating Seattle Rep by just three months. Those two the jump because they were in a small group with the Huntington and Mark Taper Forum as part of Wilson's unofficial tryout circuit, staging each new play while he was polishing it before its eventual arrival on Broadway. The even smaller group staged premieres, just three theaters, is led by Yale Rep, which did six, Ma Rainey through Two Trains and then Radio Golf. The Goodman did Seven Guitars and Gem of the Ocean, and the Pittsburgh Public, Jitney and King Hedley II. The first Jitney! (it had an exclamation point) had its premiere in 1982 at Pittsburgh's small semi-pro Allegheny Repertory Company, but the Public staged the revised, professional premiere in 1996, so you could say Jitney had its premiere in Pittsburgh twice. The Public then persuaded Wilson to delay writing King Hedley II so it and the new O'Reilly Theater could debut together in 1999.

As this suggests, Yale Rep has a good claim of being Wilson's theatrical home. So does the Huntington (as they say), since it staged the most of the plays pre-Broadway. But Wilson had several homes. Biographically, it was Pittsburgh. He was born in the Hill, lived there for 13 years, then moved a few miles to Hazelwood for a couple of years before leaving for the army and some teenage wandering. At 20 he was back on the Hill, where he embedded himself in its artistic, social and political life until he was 33. The experience of those years is the core of the Cycle, even of Ma Rainey, the only play not set in Pittsburgh. He said since it was his first play on Broadway he thought it needed a more important city, but it's just as full of the people he met and conversations he overheard in Hill diners, barbershops, backyards and jitney stations, on its street corners and porches. The Hill provided the rich brew into which he dipped the ladle of his transforming art.

However, Wilson didn't really commit himself to playwriting until he left for St. Paul, where he lived from 1978 to 1990, writing the first five plays (six, counting Jitney!); St. Paul, its Playwrights Center and Penumbra can also stake a claim (and they do) to be his theatrical home. So does Seattle, where he wrote the other plays and lived his final 15 years, until he died in 2005. There was another preeminent home along the way: Connecticut, of all places, home not just to Yale Rep but the O'Neill Theater Center. Minnesota, Connecticut and Washington: three predominantly white states where he said he could more clearly listen to those voices from the Hill.

When Wilson returned to Yale in 2005 to premiere Radio Golf, a few days before his $6{ }^{\text {th }}$ birthday, it had the feel of a reunion of the far-flung Wilson actors, some now famous, who had come to call themselves Wilsonian Soldiers. That night in New Haven was further evidence that Wilson had many homes. In the cities where theaters have dedicated themselves to his work, communities of Wilsonian actors and audiences flourish. Even 
R A W S O N : A U G U T W I L O N E S T A T E, P I T T S B U R G H P O S T -

G A Z E T T E, A N D A U G U T T I L S O N H O S E E T A B L IS H A U G U S T W I L S O C E N T UR Y C Y C LE A W A R D

\begin{tabular}{l|ll|l} 
August Wilson Journal & Vol. & 1 & Spring 2019
\end{tabular}

Broadway is one such community: he worked there on eight plays, with two to come after his death. The Edison Hotel and its coffee shop considered him a resident.

Wherever else he was working, from Boston to Kansas City, St. Louis to L.A., he found similar stage doors and diners where he could hang out. His angry testimonies about racism, the indignities of being black or just trying to get a check cashed--all evidenced his argument with America, but he was thoroughly at home in the continent-wide American theater. I was the first to call his plays the Pittsburgh Cycle, but American Century Cycle makes the justifiably more expansive claim.

At the end, Wilson was at home in Seattle, where he died, and once more in Pittsburgh, where he was brought (by his direction) for his funeral at Soldiers \& Sailors Memorial and burial in Greenwood Cemetery. But he remains most at home in the people, places and stories from what we call August Wilson's Hill, and in the theaters that bring them to life. The August Wilson American Century Cycle Award, presented jointly by his hometown newspaper and his childhood home, celebrates the conjunction of the two.

\section{Author Bio}

Mr. Christopher Rawson is senior theater critic at the Pittsburgh Post-Gazette, an emeritus member of the Pitt English Department, and an officer of August Wilson House.

\section{Photos}

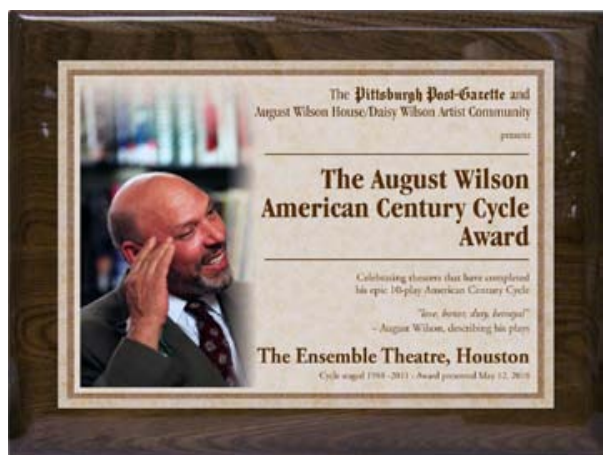

The AWACC Award plaque given to Houston's Ensemble Theatre, similar to those being gradually given to theaters that qualify.

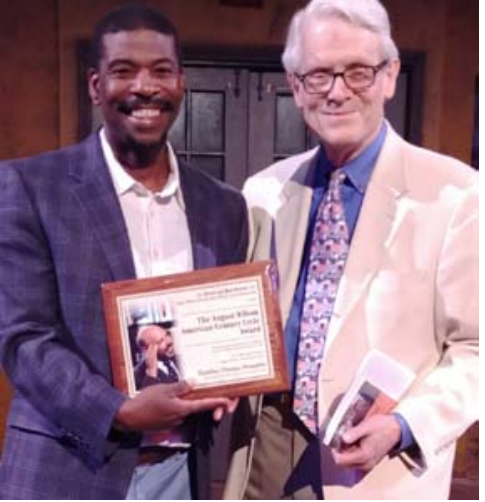

Ekundayo Bandele, founder of Hattiloo Theatre in Memphis, accepts the Cycle Award from Chris Rawson in May, 2018.

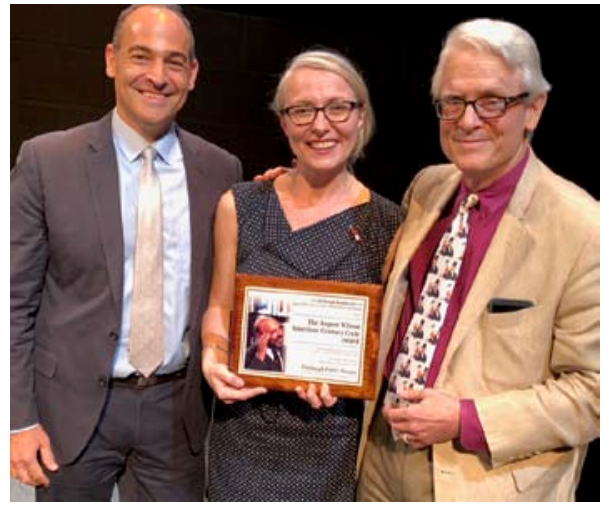

Pittsburgh Public Theater managing director Lou Castelli and artistic director Marya Sea Kaminski are presented with the Cycle Award by Chris Rawson in August, 2018. 


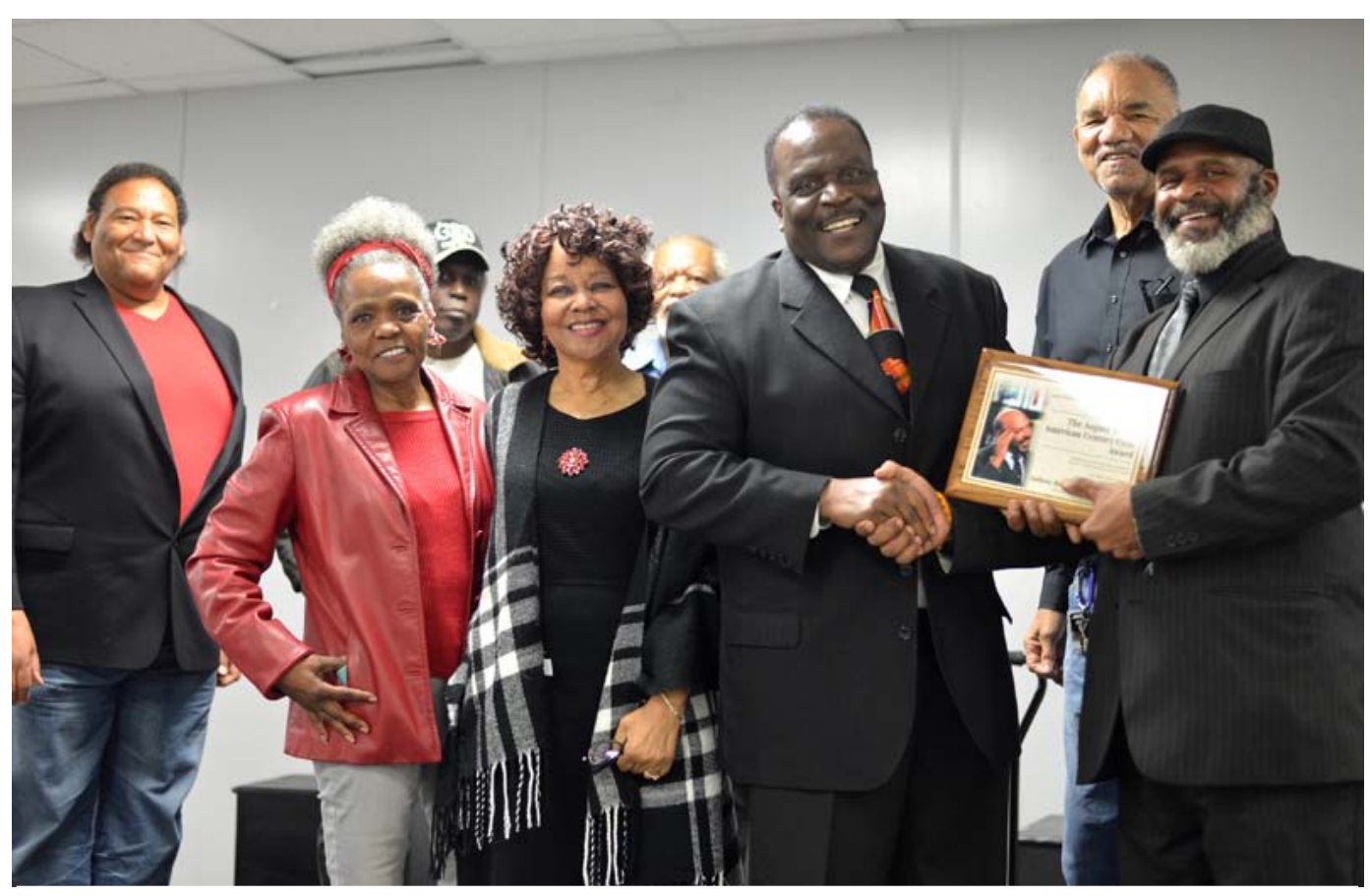

Pittsburgh actor Wali Jamal (right) presents the Cycle Award to Anthony Bean, founder of the theater in his name. Between them is Wilsonian actor Will Williams. At left are several of the company's supporters. 